\title{
"Assessing fertilizer buying behavior of emerging farmers in a South African grain producing area"
}

\begin{tabular}{|c|c|}
\hline AUTHORS & $\begin{array}{l}\text { Ronald Lotriet } \\
\text { Christo Bisschoff (D https://orcid.org/0000-0001-6845-7355 } \\
\text { Aron Kole }\end{array}$ \\
\hline ARTICLE INFO & $\begin{array}{l}\text { Ronald Lotriet, Christo Bisschoff and Aron Kole (2017). Assessing fertilizer } \\
\text { buying behavior of emerging farmers in a South African grain producing area. } \\
\text { Problems and Perspectives in Management, 15(2-2), 456-467. } \\
\text { doi:10.21511/ppm.15(2-2).2017.14 }\end{array}$ \\
\hline DOI & http://dx.doi.org/10.21511/ppm.15(2-2).2017.14 \\
\hline RELEASED ON & Wednesday, 06 September 2017 \\
\hline RECEIVED ON & Wednesday, 19 October 2016 \\
\hline ACCEPTED ON & Thursday, 19 January 2017 \\
\hline LICENSE & $\begin{array}{l}(c) \text { EY-NG } \\
\text { This work is licensed under a Creative Commons Attribution-NonCommercial } 4.0 \\
\text { International License }\end{array}$ \\
\hline JOURNAL & "Problems and Perspectives in Management" \\
\hline ISSN PRINT & $1727-7051$ \\
\hline ISSN ONLINE & $1810-5467$ \\
\hline PUBLISHER & LLC "Consulting Publishing Company "Business Perspectives" \\
\hline FOUNDER & LLC "Consulting Publishing Company "Business Perspectives" \\
\hline
\end{tabular}

NUMBER OF REFERENCES

37

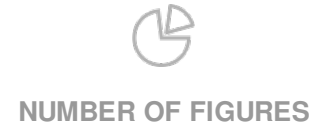

5

\section{E=-}

NUMBER OF TABLES

3

(C) The author(s) 2022. This publication is an open access article. 


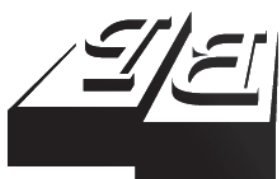

BUSINESS PERSPECTIVES

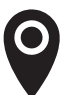

LLC "CPC "Business Perspectives" Hryhorii Skovoroda lane, 10, Sumy, 40022, Ukraine

www.businessperspectives.org

Received on: 19th of October, 2016 Accepted on: 19th of January, 2017

(C) Ronald Lotrie, Christo Bisschof, Aron Kole, 2017

Ronald Lotriet, NWU School of Business and Governance, NorthWest University, South Africa.

Christo Bisschoff, Professor, NWU School of Business and Governance, North-West University, South Africa.

Aron Kole, NWU School of Business and Governance, North-West University, South Africa.

\section{(ㄷ)(1) $(8)$}

This is an Open Access article, distributed under the terms of the Creative Commons Attribution-NonCommercial 4.0 International license, which permits re-use, distribution, and reproduction, provided the materials aren't used for commercial purposes and the original work is properly cited.
Ronald Lotriet (South Africa), Christo Bisschoff (South Africa), Aron Kole (South Africa)

\section{ASSESSING FERTILIZER BUYING BEHAVIOR OF EMERGING FARMERS IN A SOUTH AFRICAN GRAIN PRODUCING AREA}

\begin{abstract}
Fertilizer not only plays a major role in the profitability of the farmer's business, but also represents an expensive farm input. The emerging farmer market segment is expanding and holds a great deal of potential for fertilizer companies to supply the growing need for fertilizer in this market. Almost all fertilizer marketing strategies of South African companies have been designed to cater for the commercial farming sector; however, if fertilizer suppliers want to focus on the emerging farmer market segment, they need to understand buying behavior of emerging farmers, as well as their needs when developing strategies to utilize opportunities in this developing market. This study aims to identify factors playing an important role in the buying behavior of emerging farmers in the Free State when purchasing fertilizer. The results show that service, brand, product, and learning or psychological factors highly influence emerging farmers' fertilizer purchase decision. The study also finally draws recommendations and conclusions for managerial perusal
\end{abstract}

\section{Keywords fertilizer, South Africa, Free State, emerging farmers, purchase decision}

\section{JEL Classification Q13}

\section{INTRODUCTION}

In South Africa, agriculture is a crucial sector to create jobs and to grow the economy. Commercial agriculture is one of the country's most important employers, employing 5.2\% of the SA labor force. This sector particularly absorbs unskilled and semi-skilled workers with little formal education (KPMG, 2013). The primary agricultural sector directly contributes about 3\% to the country's GDP, but if the entire value chain is taken into account, its contribution to GDP reaches about 12\% (SA, 2015; Gosling \& Moolla, 2011). Food security is a major issue, and without enough production, South Africa is in danger of becoming even bigger net importer of food (that started in 2007).

The grain industry in South Africa accounts for $25-33 \%$ of the total gross value of agricultural production (SA, 2012). Grains such as barley, maize, oats, wheat, and sorghum, as well as various oilseeds (sunflower, canola, soya bean and groundnuts) make up the "Grain industry" in SA. Maize is the most important grain crop in South Africa, being both the major feed grain and the staple food of the majority of the South African population (DAFF, 2013). The largest contributor towards the gross value of field crops for the past five seasons is maize (46.1\%), followed by sugar cane (14.2\%), wheat (10.6\%), hay (8.7\%) and soya beans (7.1\%). The contribution by provinces to maize production during the 2012/13 production season is depicted in the following figure (DAFF, 2013). 


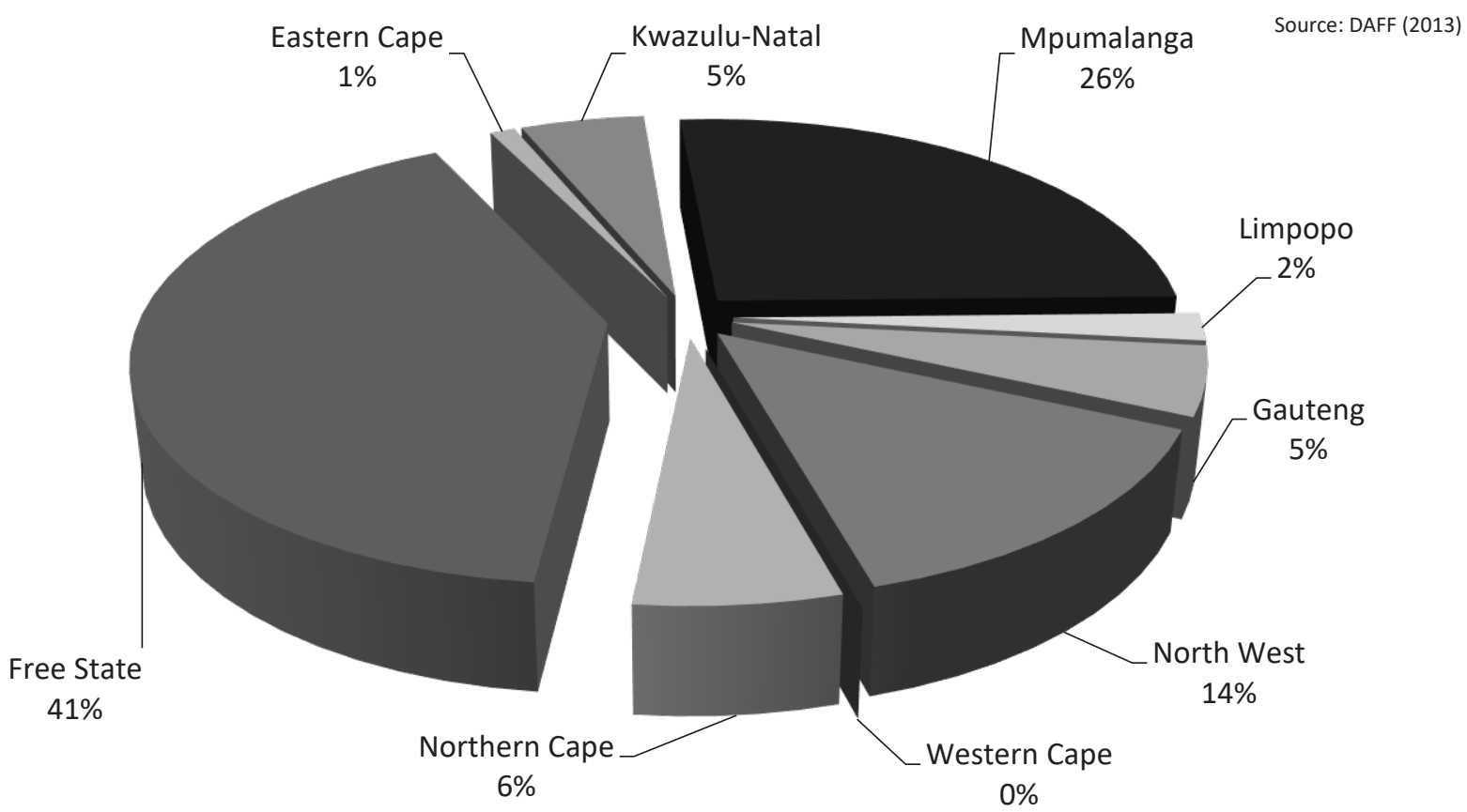

Figure 1. The provincial distribution of the maize crop in SA

The estimated area that South African commercial producers planted to maize during the 2012/13 season is 2,781 million ha. This is $3 \%$ or 82,000 ha more than the 2,699 million ha planted the previous season and $6.6 \%$ or 173,120 ha more than the five-year average of 2,608 million ha planted. The Free State province produced the most with $41 \%$ followed by Mpumalanga with $26 \%$. The Free State province also produces almost 378 million tons of wheat, which are the second most in SA (SA, 2011).

Agriculture in SA is made up of both emerging and commercially developed farmers (Armour, 2014; WWF, 2010). Until now, agricultural censuses have largely concentrated on commercial agriculture leaving out small-scale and subsistence agriculture (SA, 2016). In this regard, commercial farmers constitute between $40000-46000$, which is almost $95 \%$ of the total marketed agricultural output (Ntsebeza \& Hall, 2007, p. 143; News 24, 2013; Van Wyk, 2014). However, emerging farmers are expected to be between 1.3-3 million and situated largely in communal areas and former homelands (Machete et al., 2004). The Land and Agricultural Bank of South Africa developed a categorization model (Figure 2) to show that emergent farmers are indeed diverse (Mabaya, 2011, p. 3).

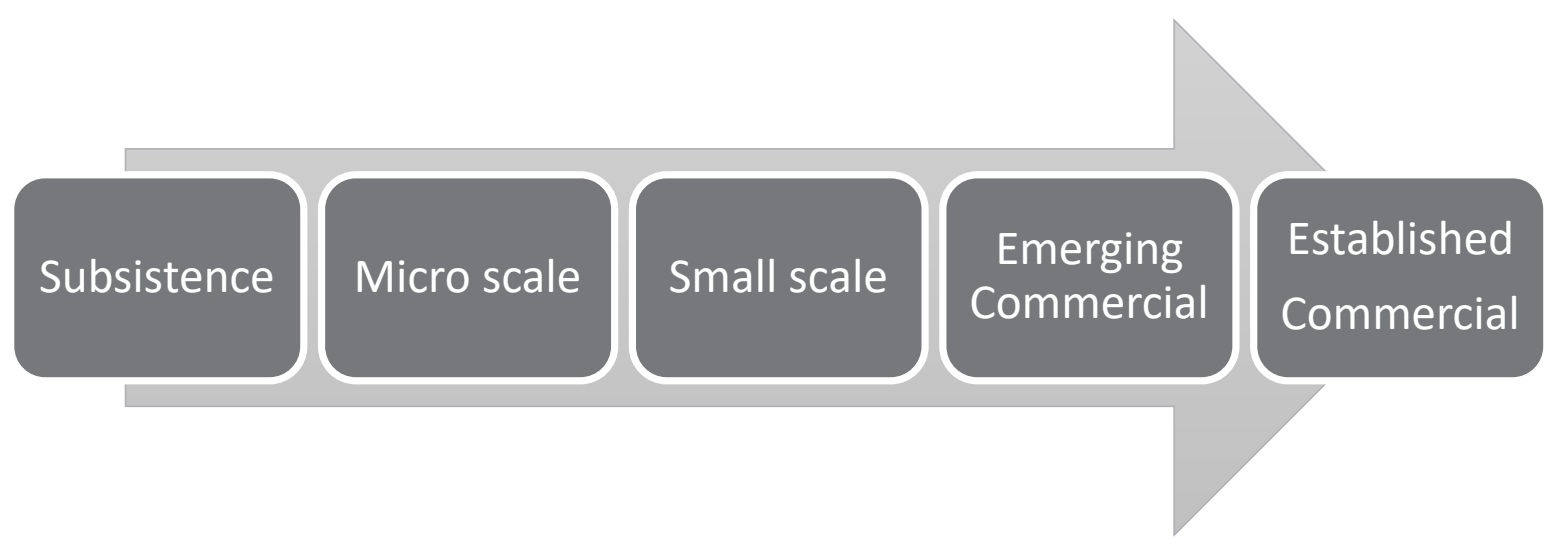

Figure 2. The agricultural sector categories in SA 
From the above, it can be inferred that the emerging farmer sector can be broadly described as previously disadvantaged farmers who are attempting to make a transition to commercially based agriculture. Many land reform schemes currently in SA give impetus to growing a new sector of emerging farmers. The smallholder farmers typically lack productive assets and produce mainly for their personal consumption instead of production for markets. The black emerging farmer is slightly more advanced than the smallholder farmer and holds more production assets, but struggles to scale up production, and has difficulty in getting connected to markets (Barlow \& Van Dijk, 2013). Amongst the cropping based farmer groups are smallholder farmers with varying capacities and desires to make a transition from survivalist farming to more commercially oriented farming systems (ACIAR, 2009).

It should be noted that significant differences exist between large commercial farmers and emerging farmers in the South African grain industry. Therefore, in this study, grain farmers are limited to crop producing farmers only. The differences provide a clearer view of their needs, requirements and subsequently, also their buying behavior.

Table 1. Differences between commercial and emerging grain farmer industry

\begin{tabular}{|c|c|c|}
\hline Activity & Average emerging farmer & Average commercial farmer \\
\hline Finance & Difficult to access finance & Easy to access finance \\
\hline Government support & High government support & Low government support \\
\hline Hectares planted & About 90 ha & About 350 ha \\
\hline $\begin{array}{l}\text { Agricultural technology, including } \\
\text { machinery and implements }\end{array}$ & $\begin{array}{l}\text { Low to none, use mostly old and } \\
\text { second-hand machinery and } \\
\text { implements. }\end{array}$ & $\begin{array}{l}\text { Use advanced technology, GPS } \\
\text { supported implements and machinery, } \\
\text { including precision agriculture }\end{array}$ \\
\hline $\begin{array}{l}\text { General fertilizer application rates, } \\
\text { planting mixtures of NPK (mostly maize) } \\
\text { especially planted in the Free State }\end{array}$ & $<200 \mathrm{~kg} / \mathrm{ha}$ & $>200 \mathrm{~kg} / \mathrm{ha}$ \\
\hline $\begin{array}{l}\text { Micro nutrients and speciality products } \\
\text { application }\end{array}$ & Barely & Frequently \\
\hline Purchasing power & Limited & Extensive \\
\hline Infrastructure & Mostly under developed & Mostly developed \\
\hline Management & Low level & High level \\
\hline
\end{tabular}

Commercial farmers are needed to nurture and support emerging farmers (News 24, 2013). This is also ile lustrated by the fact that the area planted to maize in the non-commercial agricultural sector is estimated at 26,6130 ha, which represents a decrease of $32.7 \%$ compared to the 395,200 ha of the previous season (DAFF, 2016). In many cases, advisory services provided by fertilizer companies and agribusinesses have also entered the vacuum of the under resourced government extension service (WWF, 2010).

South Africa has limited fertile land, and the majority of crop farmers need to increase the fertility of their soils to achieve good crop yields. How farmers improve or maintain soil fertility is central to the sustainability of their operation. Climate soil combinations leave only $12 \%$ of the country's surface area suitable for the production of rain fed crops. With only $3 \%$ considered truly fertile land, South Africa falls short of other countries, such as India, where arable land covers $53 \%$ of the country. The high-potential arable land comprises only $22 \%$ of the total arable land (SA, 2015).

South Africa's most recent domestic fertilizer demands are around 760,000 tons plant nutrients, Nitrogen, Phosphorus and Potassium (N + P2O5 + K2O) (FAO, 2005, p. 20). Maize and wheat are the largest consum- 


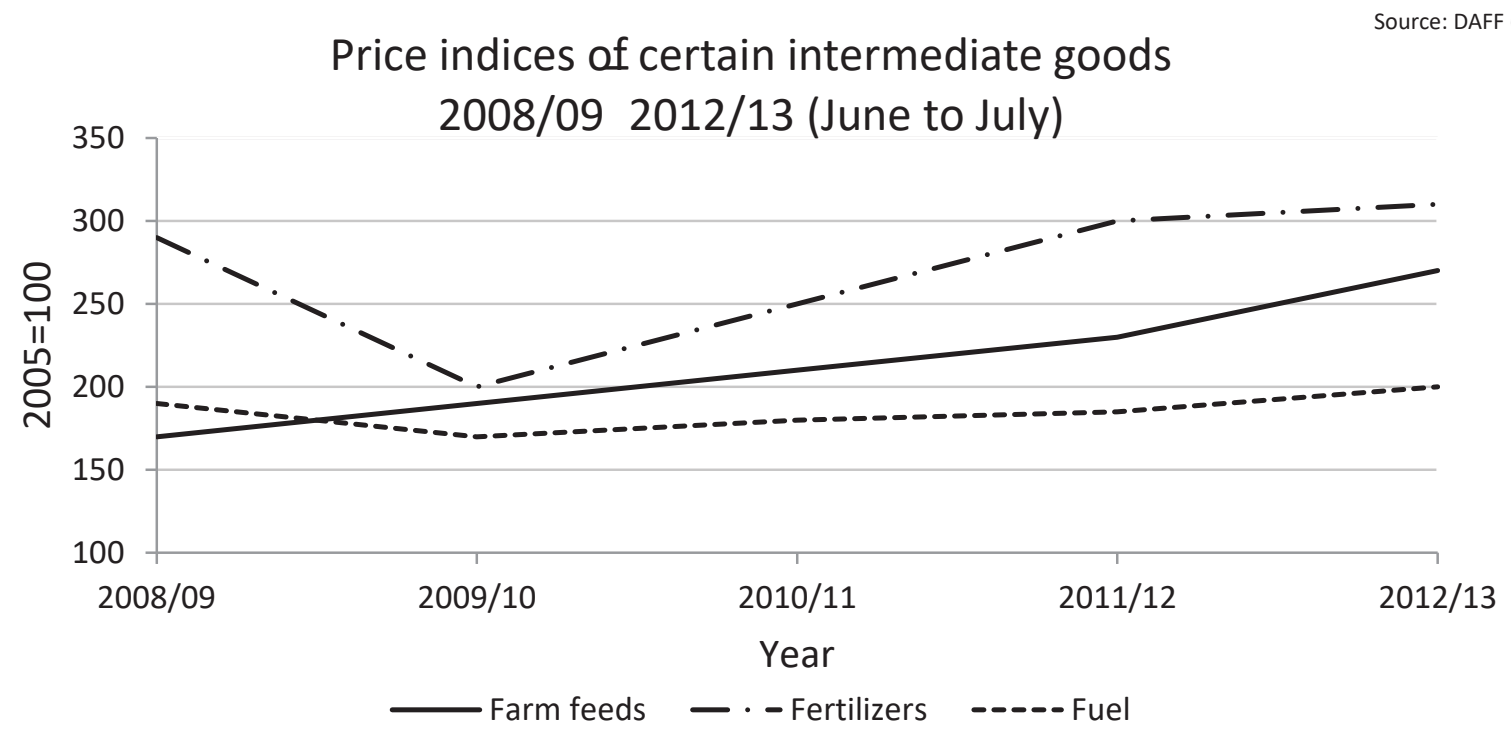

Figure 3. The three main farm inputs in SA

ers of these fertilizers; however, the mass manufacture of basic fertilizer blends (NPK) exceeds 2,2 million tons per year (SA, 2008, p. 136). Figure 3 shows the inclination of growing input costs. Clearly, fertilizer is the most expensive farm input, followed by feeds and fuel. Retail prices of these commodities are linked to the oil price and the rand/dollar exchange rate, both of which are out of the farmer's control (WWF, 2010). The combined index of prices of intermediate production inputs and services showed an increase of $11.0 \%$ for 2012/13 (DAFF, 2013):

Prices of farming requisites rose by $10.8 \%$ in $2012 / 13$, compared to an increase of $13.7 \%$ in the previous year, prices for seed increased by $19.0 \%$, fuel by $14.0 \%$, packing material by $12.9 \%$, feeds by $10.0 \%$, trucks by $9.6 \%$, dips and sprays by $9.0 \%$ fertilisers and tractors by $8.8 \%$ each, building material by $8.6 \%$, fencing material by $7.5 \%$ and maintenance and repairs by $7.0 \%$ (DAFF, 2013).

Therefore, increased yields are closely linked to fertilizer usage and application rates. Through improving the productivity of the emerging market, the food deficiency of the rural population could be alleviated and, as a consequence, increase the demand for intermediate inputs like fertilizer (SA, 2011, p. 608). However, fertilizer is one of the most expensive farm inputs for emerging grain farmers, which makes the buying decision the focal point of their farming operations. To reduce buying confusion and disagreement by consumers, fertilizer companies should enquire whether customers are satisfied with their buying decision by contacting them directly after purchase or through the use of tracking studies to evaluate levels of customer satisfaction or dissatisfaction over time (Blythe, 2013, p. 327; Lancaster \& Massingham, 2011, p. 53).

Predominately, South African farmers engage in low level subsistence agriculture, however, many emerging farmers already receive government support. Furthermore, additional support is provided by commercial producer organisations and private sector fertilizer companies with the aim of increasing productivity of smallholder agriculture. The largest target market of fertilizer companies is commercial farmers. Therefore, their marketing strategies are designed for commercial farmers and subsequently adapted to small-scale farmers.

In contradiction, the emergent sector represents a golden opportunity that has been largely ignored by the corporate sector, and it is argued that companies need to embrace the potential of this market by helping them to source materials, which can be distributed to them as well (Jiang, 2015). A great deal of government developmental program exist. The South African Comprehensive Agricultural Support Program (CASP) and the Farmer Recapitalization Program (RECAP) are both assisting emerging farmers. 


\section{PURPOSE}

The number of emerging farmers in South Africa grew into a substantial market segment, creating an opportunity for fertilizer companies to engage. As this is a new market segment, the buying behavior of these farmers is unfamiliar, and, as a result, to successfully enter this market segment, research in buying behavior is needed. A better understanding of emerging farmers' buying behavior would improve fertilizer company's chances to prosper in this market in future. This would be a result of incorporating and adapting their marketing strategies to the changes in the South African agricultural environment, thus, serve the needs of their new farmer-customers better. The purpose of the study is, therefore, to identify the factors that play an important role in the buying behavior of emerging farmers when buying fertilizer.

\section{LITERATURE REVIEW}

Farmers are faced with various complex choices today, and, as such, it is important for a fertilizer company to understand the buying behavior of the targeted customer.

\section{The consumer decision-making process}

Decision-making is a complicated process. The process consists of five stages; they are:

- Need recognition. Buying behavior is activated by the customer sensing a need. If this need is backed up by money (or purchasing power), an economic demand realizes, and there is a mark for products that could satisfy the need.

- Information search. Following need recognition, the customer (or, in this case, the emerging farmer), requires information on the different products that could satisfy the need. Various sources of information exist. Additionally, a number of influential factors play a role in the final decision taken by the customer. This is more so in the event of more expensive product. Hence, emerging grain farmers buying an expensive production, such as fertilizer, would show exten- sive involvement in decision-making before reaching the final step of the actual purchase. Typically they would consider views held by various reference groups or opinion leaders, where the word-of-mouth process would play an important role in their buying behavior (Kotler \& Armstrong, 2012, p. 163). Du Plessis et al. (2007, p. 67) describe opinion leaders as people in the buyer's reference group who possess specific knowledge or skills, personality or some other characteristics, which make them worthy of consulting as exert in a buying decision. Both agricultural organizations and farmer associations are suitable to act as opinion leaders and reference groups when advice regarding the buying of fertilizer is needed. In fact, many emerging farmers regard their fertilizer company's agricultural adviser as a trusted opinion leader, and consequently they follow their advice stringently when they make their fertilizer (and sometimes also with other farming production inputs) buying decisions.

- Evaluation of alternatives. Having armed himself/herself with the information on alternative products that could satisfy the need, the farmers is, then, involved in a process to evaluate the various (attractive) options available. Farmers are at liberty to compare and analyze the alternatives, even revert to more information sourcing, before they make a final decision, namely to purchase, and, if so, which product from what supplier (Quester et al., 2011, p. 228). Here fertilizer companies equip their agricultural advisors well so that they can assist farmers in making the correct decision; this is especially important in the case of emerging farmers who have limited experience and knowledge. In this stage, the marketing strategies should focus on product awareness, assistance in physical distribution (delivery), product benefits and product availability (Lantos, 2011, p. 439). It is also important that the fertilizer company's agricultural advisor explains well the attributes of the specific fertilizer mixture and the application thereof during the growth stages of the crops. This, in addition to the brand, product quality and product 


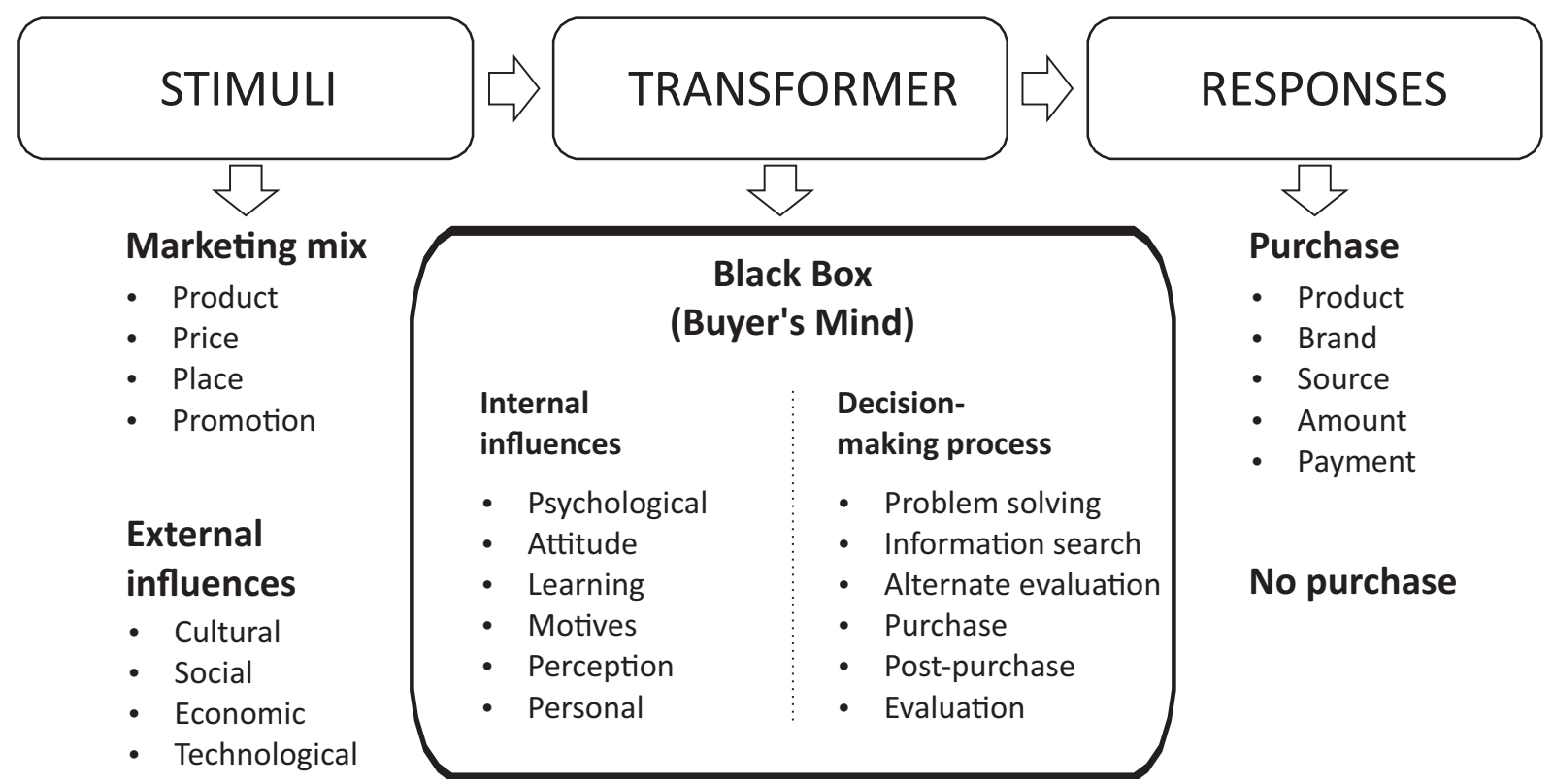

Figure 4. The stimulus response model

form (granules of liquid fertilizer) can influence buying purchase behavior (Peter \& Donnelly, 2011, p. 43).

Homburg et al. (2009, p. 139) state that brand loyalty (also in the agriculture) plays a big role on buying behavior. Brands are associated with quality and are transferable among generations. In this regard, the quality of the fertilizer could be an area of differentiation between fertilizer companies. Chaudhuri $(2012$, p. 125) states that stronger brands achieve higher levels of repeated purchases. Resultantly, the better fertilizer company brands may achieve bigger market share among emerging farmers. Brand management, therefore, is key to capture the emerging farmer fertilizer market. Quality fertilizer is important, because it contributes to the crop yield hence profits that the farmer makes (Blythe, 2008, p. 10).

- Buying decision. Once all options are considered the farmer makes the final buying decision. Here the marketing mix (offering a product at a certain price, after being promoted and then distributed to where the customer can buy the product) plays a significant role to influence the final buying deci- sion. Farmers need to decide if the product is priced competitively, is of the required quality, and if the company can deliver the fertilizer on time at the farm (hence, performing the distributing products).

- Post-purchase behavior. The final stage of the buying behavior process is to evaluate the purchase. In some cases, this evaluation is immediate (such as drinking the soft drink just bought), while in other cases such as fertilizer, the final evaluation can only be made once the crops are harvested. The farmer will use this post-purchase evaluation are part of his next buying decision as an information source before he re-buys the specific fertilizer brand or mixture.

Buying behavior can also be explained by the Stimulus Response Model where the external and internal influences, the marketing mixture and the buying decision is incorporated. The model is depicted in Figure 4.

Figure 4 depicts the influences that the marketing mixture and other stimuli have the so-called "buyer's black box" and how they produce certain responses. The buyer's mind (the "black box") receives various stimuli, while the buying response 
remains uncertain. Due to a large number of stimuli and influences, consumers may act inversely to the marketer's expectations by refusing to buy the product, although in most rational decisionmaking scenarios an expected outcome realizes (Saxena, 2009, p. 143).

External factors can also influence the farmer's final buying decision. Typically aspects such as culture (Kumar, 2009, p. 253; Sarangapani, 2009, p. 15), social influences (Kardes et al., 2009, p. 301; Hoyer \& Maccinis, 2008, p. 49), technological and economic influences (Van Rensburg et al., 2011, p. 7) play a role.

Internal factors that could influence farmer buying behavior include psychological influences, perceptions, attitudes and personal influences like age and income (Kumar, 2010, p. 223). The buyer's perception of the product, advisor ar any other buying influence, could also affect the final decision to purchase or not. In this regard, Quester et al. (2011, p. 228) mention that perceptions are a critical part of the information processing system. Learning is also important, especially in a market where low technical expertise and limited product knowledge exists (such as the emerging farmers' market) (Lantos, 2011 , p. 439). Organizations, therefore, need to understand how, where and when farmers learn to integrate product information best so that they can incorporate it into their marketing strategies. Once farmers are satisfied with their purchased fertilizer, they might move into habitual or routine buying behavior (Wankel, 2009, p. 370).

\section{RESEARCH METHODOLOGY}

\subsection{Study population}

The study population consisted of 32 emerging grain farmers from the Free State province in South Africa. As a result, no sample was drawn, and all farmers were included in the study. These farmers farm with gain and for the purpose of the study, the grain industry includes both oilseeds and grains. Small holder, developing and subsistence farmers are defined as emerging farmers in this study.

\subsection{Collection of data}

The emerging farmers targeted in this study are located throughout the province. Data were collected via interviews, because the farmers generally have low literacy levels. This also resulted in extra time spent to explain the study aims. This had to be done in person, and, as a result, data collection required substantial travelling. The researcher visited organized farmer activities such as farmers' associations, farmer gatherings and information days to collect the data. The questionnaire was drafted in English and Sesotho (this is the mother tongue of the emerging farmers in the province). As a result, the respondents showed a high understanding of the questions.

\subsection{Measuring instrument}

A structured questionnaire consisting of 30 questions was drafted. The questionnaire measured farmer perceptions on their fertilizer buying behavior and the role industry plays in their farming success on a 5-point Likert scale, where five indicated "importance" versus one that indicated "non-importance" with the question.

\section{DISCUSSION OF RESULTS}

\subsection{Section: demographic profile}

The respondents were demographically profiled based on their gender, age, years of farming experience, farm size (hectare), fertilizer application rate per hectare and from whom they purchase fertilizer.

The results indicate that:

- As expected in a physically demanding activity such as farming, most of the emerging farmers are men $(90.6 \%)$.

A third of the farmers are between 36-45 years old. Encouraging is the fact that almost all (93\%) are younger than 60 years old, while $15.6 \%$ are aged between $26-35$ years.

- Some $15.6 \%$ of farmers are new to farming with 3 years or less experience. Some $37.5 \%$ 
of the farmers have 4-10 years farming experience, and only $4 \%$ have more than 20 years experience on the farm.

- Most farmers (68.8\%) are relatively small scale farmers (about commercial farm in the Free State). They cultivate less than 250 hectares. The common farm size ranges between 60-150 hectares. However, some $15.6 \%$ have larger farms. They cultivate 500 hectares and more.

- $\quad$ Most farmers (71.9\%) apply less than $250 \mathrm{~kg}$ of fertilizer per hectare. Only $28.1 \%$ apply more than $250 \mathrm{~kg}$ of fertilizer per hectare.

- The representatives of the fertilizer companies are the supplier in the majority of transactions (45.2\%). Next, farmers purchase fertilizer from agents (38.7\%), while only $16.1 \%$ buy fertilizer from established agricultural co-operatives.

\subsection{Perceptions of the fertilizer industry by emerging farmers}

The responses to the 30 questions on the fertilizer industry (as viewed by the emerging farmers) indicate that:

- Some $69 \%$ believe that the fertilizer industry has an understanding of their farming needs and that the fertilizer industry plays an important role to play in their farming businesses. However, $21.9 \%$ believe fertilizer companies do not understand the farming needs of emerging farmers.

- Two thirds of the respondents believe that the fertilizer companies are progressive and improving.

- Interestingly, $62.5 \%$ feel that fertilizer companies have a direct impact on their farming profitability.

- Some $78.2 \%$ do understand how the fertilizer industry works.

- The majority $(90.7 \%)$ believe that the fertilizer company they buy fertilizer from, provide them with fast service and $84.4 \%$ of them perceive that these fertilizer companies do provide services specific to their farming needs.

- Emerging farmers (75\%) also believe that fertilizer companies differentiate their products from that of their competitors.

- Most farmers (90.6\%) agree that the fertilizer company they buy from provides them with technical/agronomic services. Some 9.4\% believe they do net get these services.

- Most farmers (87.1\%) are also happy to do business with their fertilizer supplier.

The majority of respondents (84.4\%) feels that buying fertilizer is an easy and uncomplicated process, and $81.2 \%$ of them indicated that they would continue.

- To buy from their current fertilizer supplier. The flexibility of the fertilizer company to do business is also pointed out as important in the re-buy decision.

Almost all of the farmers (87.6\%) are satisfied that the fertilizer company provides them with good product information. They are also satisfied with the quality of the fertilizer and do believe that using fertilizer add value to the crops.

- $84.4 \%$ feel that fertilizer company representatives should continue to conduct farm visits as part of the service offering, and 75\% indicated that this should continue as aftersales services.

- Most (87.1\%) believe that the fertilizer companies add value to their farming operations.

- $90.3 \%$ consider the delivery of fertilizer products (transportation services) as key to their buying decision. This is expected, as emerging farmers have limited infrastructure and few possess transport capabilities.

- $73.3 \%$ of the respondents believe agricultural organizations which they are members of play a role in their fertilizer purchase decisions and only $10 \%$ of the respondents don't. 
Table 2. Reliability of the data

\begin{tabular}{l|c|c}
\hline \multicolumn{1}{c|}{ Category } & Cronbach's Alpha & Number of items \\
\hline 1. Fertilizer industry in general & .961 & 5 \\
2. Perception of farmers about the company, agents, and distributors \\
from which they buy fertilizer
\end{tabular}

Note: all categories were found to be reliable except Category $3(.365)$.

- $65.5 \%$ of the respondents believe advertisements influence their purchase decisions, while $10.3 \%$ do not believe that with almost a quarter $(24.1 \%)$ of the respondents neutral.

- Interestingly price is not the key criterion in the buying decision of fertilizer. Some $69 \%$ do not purchase the cheapest fertilizer products. Trust in the company and its representative, as well as additional services, play a role in selecting a fertilizer supplier. Here the majority (83.4\%) considers support and services as important choice criteria that influence the fertilizer buying decision.

- Some $73.3 \%$ of the farmers are brand loyal when it comes to their preferred fertilizer brand and would rather wait for their brand to become available than to buy a competitive brand. Here $80 \%$ indicated that they always buy the same brand of fertilizer. They of them also indicated that they buy only reputable $(73.3 \%)$ and stable $(89.3 \%)$ fertilizer brands.

\subsection{Mean values of categories}

The mean values of all factors were calculated and converted into percentage format. Mean values more or equal to 3 on a 5 -point scale (or, then, $60 \%$ ) are important, while those equal or above 3.5 (75\%) are very important.

The questionnaire consists of four categories:

- Category 1 (Q1-Q5). I understand how the fertilizer industry works, displayed the lowest mean percentages.

- Category 2 (Q6-Q19). The perceptions about the fertilizer company, agents, and distributors from which they buy (Q6-Q19). Here,

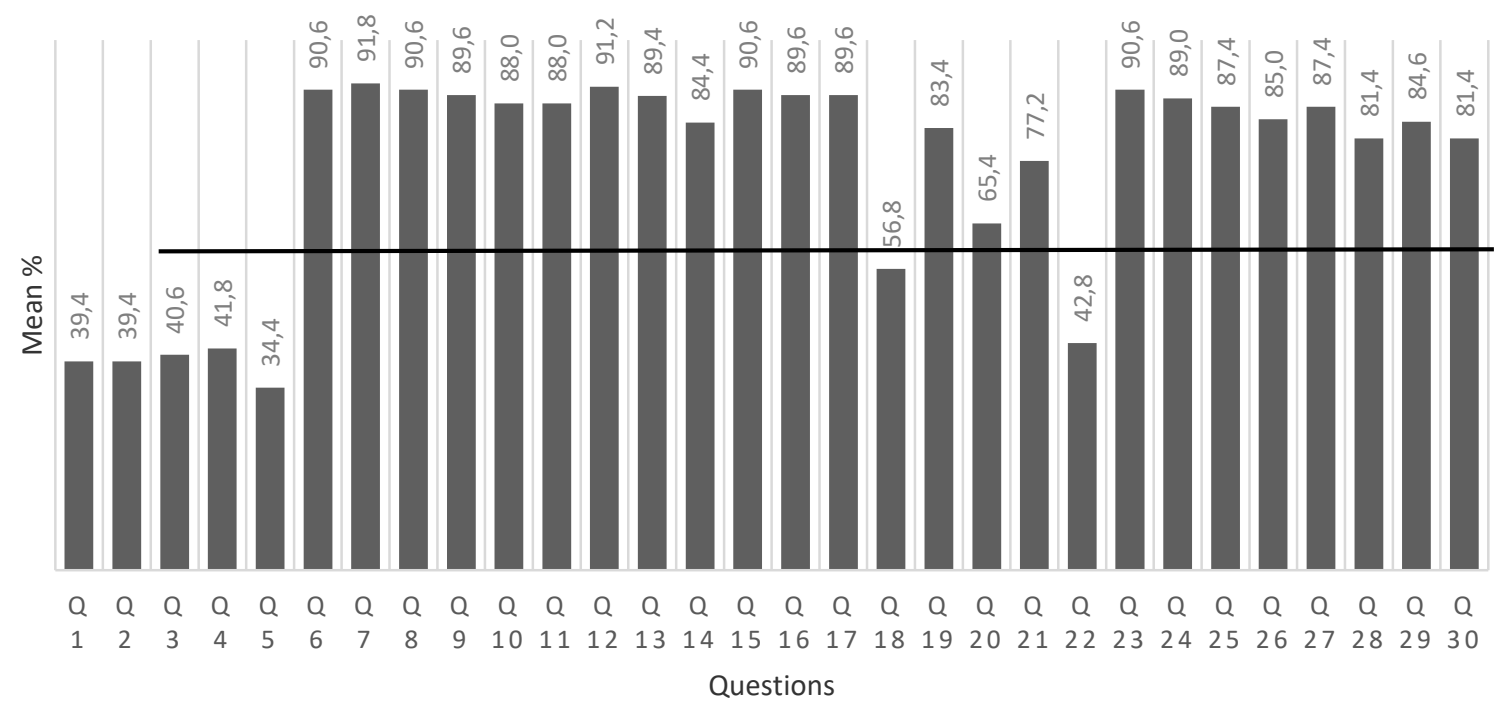

Figure 5. Mean values of all categories 
Table 3. Correlation analysis

\begin{tabular}{|c|c|c|c|c|c|c|}
\hline \multicolumn{3}{|c|}{ Category } & \multirow{2}{*}{$\frac{\text { Age }}{1.000}$} & \multirow{2}{*}{$\frac{\text { Farming experience }}{.386^{*}}$} & \multirow{2}{*}{$\frac{\text { Area planted }}{.114}$} & \multirow{2}{*}{$\frac{\text { Fertilizer use }}{.074}$} \\
\hline \multirow{12}{*}{ Spearman's rho } & \multirow{3}{*}{ Age } & $\begin{array}{l}\text { Correlation } \\
\text { Coefficient }\end{array}$ & & & & \\
\hline & & Sig. (2-tailed) & & .029 & .534 & .687 \\
\hline & & $N$ & 32 & 32 & 32 & 32 \\
\hline & \multirow{3}{*}{$\begin{array}{l}\text { Farming } \\
\text { experience }\end{array}$} & $\begin{array}{l}\text { Correlation } \\
\text { Coefficient }\end{array}$ & $.386^{*}$ & 1.000 & $.503^{* *}$ & $.451^{* *}$ \\
\hline & & Sig. (2-tailed) & .029 & & .003 & .010 \\
\hline & & $\mathrm{N}$ & 32 & 32 & 32 & 32 \\
\hline & \multirow{3}{*}{$\begin{array}{l}\text { Area } \\
\text { planted }\end{array}$} & $\begin{array}{l}\text { Correlation } \\
\text { Coefficient }\end{array}$ & .114 & $.503^{* *}$ & 1.000 & $.727^{* *}$ \\
\hline & & Sig. (2-tailed) & .534 & .003 & & .000 \\
\hline & & $N$ & 32 & 32 & 32 & 32 \\
\hline & \multirow{3}{*}{$\begin{array}{l}\text { Fertilizer } \\
\text { used }\end{array}$} & $\begin{array}{l}\text { Correlation } \\
\text { Coefficient }\end{array}$ & .074 & $.451^{* *}$ & $.727^{* *}$ & 1.000 \\
\hline & & Sig. (2-tailed) & .687 & .010 & .000 & \\
\hline & & $N$ & 32 & 32 & 32 & 32 \\
\hline
\end{tabular}

Note: ${ }^{\star}$. Correlation is significant at the 0.05 level (2-tailed). ${ }^{* *}$. Correlation is significant at the 0.01 level (2-tailed).

Q7 (providing specific services to farmers' needs) and Q12 (Providing good information about company fertilizer product) had the highest percentages. Both these criteria are service related issues. This is understandable because learning and psychological factors and information about fertilizer products have both been identified as very important criteria when an emerging farmer considers buying fertilizer products.

- Category $3(\mathrm{Q} 20-\mathrm{Q} 26)$ is about influences on farmer purchase decisions.

- Category 4 (Q27-Q30) deals with farmer perceptions about different fertilizer brands.

The line of importance (60\%) in Figure 5 indicates which factors are regarded as important (above the line) and those not (below the line) in buying behavior of fertilizer by emerging farmers. In addition to not understanding how the industry works (Q1-Q5), only family (Q18) and the influence of price on fertilizer buying decisions (Q22) are regarded as the not-so-important buying behavioral factors that influence the emerging farmers. Figure 5 also shows that ser- vice, brand, product and psychological factors are important factors that influence fertilizer buying behavior.

\section{RELIABILITY}

Cronbach's Alpha coefficient was used to statistically measure the reliability of the data (Pallant, 2013, p. 104). A high level of reliability indicates that the same construct is measured by the questions in the questionnaire. An Alpha coefficient of 0.7 or higher is regarded as acceptable reliability. The Alpha coefficients appear in Table 2.

\subsection{Correlation analysis}

Spearman's correlation coefficient is used in non-parametric data (Pallant, 2013, p. 107). Table 3 showed a significant correlation bei tween the Area planted and Fertilizer used $\left(r_{s}=0.727, p \leq 0.01\right)$. Further significant correlations were found between Age and Farming $\left(r_{s}=0.386, p \leq 0.05\right)$; Farming and Area planted $\left(r_{s}=0.503, p \leq 0.01\right)$; and Farming and Fertilizer used $\left(r_{s}=0.451, p \leq 0.01\right)$. 


\section{CONCLUSION AND RECOMMENDATIONS}

The literature review indicated that very limited research is being conducted on fertilizer buying behavior by emerging farmers. The aim of the study was to identify factors playing an important role in the buying behavior of emerging farmers in the Free State when purchasing fertilizer. Data analysis identified service with an average mean of 4.15 (83\%); product with $4.25(85 \%)$, brand with $4.18(83.6 \%)$ and psychological/learning with an average mean of $4.45(89 \%)$ as the most important factors in this regard.

This study revealed that the methods the fertilizer companies need to consider when targeting the emerging farmer market in the Free State province. Emerging farmers need to be mentored in the use of fertilizer and basic principles of fertilization. Therefore, the following recommendations should be considered by fertilizer companies:

- Fertilizer companies need to identify the opinion leaders in the fertilizer market segment to form possible alliances and consequently to create a trust foundation with emerging farmers.

- Emerging farmers prefer buying fertilizer from companies that provide after sales services, visit their farm regularly, simple buying procedures, and delivery services.

- Fertilizer companies should frequently advertise during events such as farmer information days to create constant awareness of fertilizer products or new product offers.

- Fertilizer companies should also offer good quality products at competitive prices and differentiate their products.

Lastly, being the cheapest fertilizer supplier is not a good marketing strategy, as emerging farmers do not necessarily purchase the cheapest fertilizer. Thus, future profit potential lies in the emergent sector, but it is in demand of a "bottom-of-the-pyramid" approach to serving this sector and developing the products and services required in a culturally significant and sustainable way. Fertilizer companies should develop a new business model that to combines low cost, quality, sustainability, and profitability. This business model will only be created through a long-term customer-centric investment approach.

\section{REFERENCES}

1. ACIAR. (2009). Development of emerging farmer croplivestock systems in northern RSA. Retrieved from http:// aciar.gov.au/project/lps/2002/081 (accessed on 27.06.2016).

2. Armour, J. (2014). Dualism in SA Agriculture. Retrieved from http://www.fssa.org.za/Journals/2014/Armour_slides.pdf (accessed on 22.06.2014).

3. Barlow, L., \& van Dijk, N. (2013). Market Investigation of Black Emerging Farmers in South African Horticulture. Retrieved from http://www.iccokia.org/ southernafrica/assets/File/ Market\%20Investigation\%20
Black\%20Farmers_December\%202013_Final\%20(NVD). pdf (accessed on 27.06.2016).

4. Blythe, J. (2008). Consumer behavior. London: Thompson Leaning.

5. Blythe, J. (2013). Consumer behavior (2nd ed). London: Sage.

6. Chaudhuri, A. (2012). Emotion and reason in consumer behavior. New York, NY: Elsevier.

7. DAFF. (2013). Trends in the agricultural sector. Retrieved from http://www.daff.gov.za/ docs/statsinfo/Trends 13.pdf (accessed on 27.06.2016).
8. Du Plessis, F., Rousseau, D., Boshof, C., Ehlers, L., Engelbrecht, M., Joubert, R., \& Sanders, S. (2007). Buyer behavior. Understanding consumer psychology and marketing (4th ed). Cape Town: Oxford.

9. Gosling, M., \& Molla, Y. (2011). South Africa’s ever-shrinking farmers. The Mercury. Retrieved from http://www.iol.co.za/mercury/south-africas-ever-shrinkingfarmers-1167943 (accessed on 22.06.2016).

10. Homburg, C., Kuester, S., \& Krohmer, H. (2009). Marketing Management: A contemporary perspective. New York, NY: McGraw Hill. 
11. Hoyer, W. D., \& Maccinis, D. J. (2008). Consumer behavior (5th ed). New York, NY: South Western, Cengage learning.

12. Jiang, Q. (2015). Business at the bottom of the pyramid. Retrieved from http://www.capechameleon. co.za/online-articles/news-arena/ (accessed on 22.06.2016).

13. Kardes, F. R., Cronley, M. L., \& Cline, T. W. (2011). Consumer behavior. New York, NY: SouthWestern, Cengage learning.

14. Kotler, P., \& Armstrong, G. (2012). Principles of marketing (14th ed). London: Prentice Hall.

15. KPMG. (2013). The state of agriculture in South Africa. Retrieved from http://www.sablog kpmg.co.za/2013/12/state-agriculture-south-africa/ (accessed on 22.06.2016)

16. Kumar, S. R. (2009). Consumer behavior and branding. New Delhi: Pearson education.

17. Kumar, P. (2010). Marketing of Hospitality and Tourism services. New Delhi: Tata McGraw Hill.

18. Lancaster, G., \& Massingham, L. (2011). Essentials of marketing management. New York, NY: Routledge.

19. Lantos, G. P. (2011). Consumer behavior in action: Real-life applications for marketing managers. New York, NY: M.E. Sharpe.

20. Mabaya, E., Tihany, K., Karaan, M., \& Van Rooyen, J. (2011). Case Studies of Emerging Farmers and
Agribusinesses in South Africa. Retrieved from http://www.africansunmedia.co.za/Portals/0/files/ extracts/Case\%20Studies\%20Extract.pdf (accessed on 27.06.2016).

21. Machete, C. L., Venter, G. C. H., Mothabele, M., \& Ngobese, P. (2004). Paper presented at the Regional Fertilizer Trade, Marketing and Distribution Conference, 22-26 February. Pretoria: (Unpublished).

22. News 24. (2013). Loss of commercial farmers worrisome. Retrieved from http://www. news24.com/ SouthAfrica/Politics/Loss-of-commercial-farmersworrisome-20130324 (accessed on 22.06.2016).

23. Ntsebeza, L., \& Hall, H. (2007). The land question in South Africa. Cape Town: HSRC.

24. Pallant, J. (2013). SPSS Survival Manual. McGraw-Hill: New York.

25. Peter, J. P., \& Donnelly (Jr), J. H. (2011). A preface to marketing management (12th ed). New York, NY: McGraw-Hill.

26. Quester, P. G., Pettigrew, S., \& Hawkins, D. I. (2011). Consumer behaviour: Implications for marketing strategy (6th ed). North Ryde: McGraw Hill.

27. Sarangapani, A. (2009). A textbook on rural consumer behavior in India. New Delhi: University science.

28. Saxena, R. (2009). Marketing management (4th ed). New Delhi: McGraw-Hill.
29. South Africa. Department of Agriculture. (2011). National agricultural directory. Pretoria: Government printers.

30. South Africa. Department of Agriculture. (2012). Abstract of agricultural statistics, 2011. Pretoria: Government printers.

31. South Africa. Department of Trade and Industry. (2008). The Report: South Africa. Cape Town: Oxford Business Group.

32. South Africa. (2015). SA Yearbook 2014/5. Retrieved from http:// www.gcis.gov.za/content/resourcecentre/sa-info/yearbook2014-15 (accessed on 27.06.2016).

33. Stats, S. A. (2016). Agricultural Statistics. Retrieved from http:// www.statssa.gov.za/?page $\mathrm{id}=735 \& \mathrm{id}=4$ (accessed on 22.06.2016)

34. Van Rensburg, J. J., McConnell, C. R., \& Brue, S. L. (2011). Economics: Southern African edition. New York, NY: McGraw-Hill.

35. Van Wyk, A. (2014). Do 40000 whites own $80 \%$ of South Africa? Retrieved from http://mg.co.za/ article/2014-09-15-do-40-000whites-own-80-of-south-africa (accessed on 22.06.2016).

36. Wankel, C. (2009). Encyclopaedia of business in today's world. London: Sage.

37. WWF. (2010). Agriculture: facts \& trends South Africa. Retrieved from http://awsassets.wwf. org.za/downloads /facts_brochure_mockup.pdf (accessed on 27.06.2016). 